\title{
Production of Basal Bodies in bulk for dense multicilia
}

\section{formation [version 1; peer review: 2 approved]}

\author{
Xiumin Yan, Huijie Zhao, Xueliang Zhu
}

State Key Laboratory of Cell Biology, CAS Centre for Excellence in Molecular Cell Science, Institute of Biochemistry and Cell Biology, Shanghai Institutes for Biological Sciences, Chinese Academy of Sciences, Shanghai, China

V1 First published: 28 Jun 2016, 5(F1000 Faculty Rev):1533

https://doi.org/10.12688/f1000research.8469.1

Latest published: 28 Jun 2016, 5(F1000 Faculty Rev):1533

https://doi.org/10.12688/f1000research.8469.1

\section{Abstract}

Centriole number is normally under tight control and is directly linked to ciliogenesis. In cells that use centrosomes as mitotic spindle poles, one pre-existing mother centriole is allowed to duplicate only one daughter centriole per cell cycle. In multiciliated cells, however, many centrioles are generated to serve as basal bodies of the cilia. Although deuterosomes were observed more than 40 years ago using electron microscopy and are believed to produce most of the basal bodies in a mother centriole-independent manner, the underlying molecular mechanisms have remained unknown until recently. From these findings arise more questions and a call for clarifications that will require multidisciplinary efforts.

\section{Keywords}

ciliogenesis, centriole assembly, Deuterosome, deuterosomedependent

\section{Open Peer Review \\ Approval Status \\ 2 \\ version 1 \\ 28 Jun 2016 \\ Faculty Reviews are review articles written by the prestigious Members of Faculty Opinions. The articles are commissioned and peer reviewed before publication to ensure that the final, published version is comprehensive and accessible. The reviewers who approved the final version are listed with their names and affiliations.}

1. Steven Brody, Washington University School of Medicine, St. Louis, USA

2. Giuliano Callaini, University of Siena, Siena, Italy

Any comments on the article can be found at the end of the article. 
Corresponding author: Xueliang Zhu (xlzhu@sibcb.ac.cn)

Competing interests: The authors declare that they have no competing interests.

Grant information: The authors are supported by grants from the National Science Foundation of China (31330045) and the Ministry of Science and Technology of China (2012CB945003).

The funders had no role in study design, data collection and analysis, decision to publish, or preparation of the manuscript.

Copyright: ( 2016 Yan X et al. This is an open access article distributed under the terms of the Creative Commons Attribution License, which permits unrestricted use, distribution, and reproduction in any medium, provided the original work is properly cited.

How to cite this article: Yan X, Zhao H and Zhu X. Production of Basal Bodies in bulk for dense multicilia formation [version 1; peer review: 2 approved] F1000Research 2016, 5(F1000 Faculty Rev):1533 https://doi.org/10.12688/f1000research.8469.1

First published: 28 Jun 2016, 5(F1000 Faculty Rev):1533 https://doi.org/10.12688/f1000research.8469.1 


\section{Introduction}

The centriole is a cylinder-shaped organelle that serves as the core of the centrosome or the basal body of the cilium ${ }^{1-5}$. Nascent centriole formation usually depends on pre-existing mother centrioles. Normally in one cell cycle each mother centriole produces only one daughter centriole, that is directly adjacent (Figure 1). Such tight control ensures proper mitosis, since only two centrosomes are required to function as the spindle poles. It also guarantees that the centriole number remains constant after cell division (Figure 1).

Ciliogenesis occurs at the G0 or G1 stage of the cell cycle (Figure 1) $)^{1,3,6}$. In vertebrates, most cells can possess a primary cilium, which functions as a sensory organ for diverse environmental signals. Mammalian epithelial tissues such as those lining the inner surface of the trachea, the oviduct, and the brain ventricles, however, have abundant multiciliated cells (MCCs) with hundreds of cilia (Figure 1). These multicilia are motile and their beating is critical for mucus clearance, ovum transport, or cerebrospinal fluid circulation 7 . How then do such cells generate sufficient numbers of basal bodies?

The mystery was initially uncovered by electron microscopy (EM) on a variety of MCC-containing tissues in the 1960's and 1970's. The mother centriole was observed to be surrounded by multiple daughter centrioles in MCCs. Moreover, many granular or ringshaped EM structures termed deuterosomes (this name will be used in this review), procentriole precursor bodies, dense granules, and generative complexes were also able to initiate procentriole assembly ${ }^{8-12}$. Importantly, the deuterosomes were estimated to produce most of the basal bodies required. Nevertheless, it is only recently that we have begun to understand the molecular mechanisms involved, which will be the major focus of this review.

\section{Mother centriole-dependent centriole assembly}

Tremendous progress has been made toward understanding how a daughter centriole is born in cycling cells. A group of proteins, including Cep152 and Cep63, are specifically located around the proximal side of the mother centriole. In the G1 phase, the pololike kinase PLK4 binds to Cep152 to form the site of centriole assembly ${ }^{13-17}$. In the $S$ phase, a cartwheel structure is formed at the PLK4 site, followed by the assembly of the nine sets of microtubule triplets and other components of the daughter centriole. Centriole assembly is completed by the G2 phase and, following mitosis, each daughter cell inherits a mother-daughter pair of centrioles (Figure 1) $)^{1-5}$.

Interestingly, mother centrioles in cycling cells are capable of generating more than one daughter centriole. For instance, overexpression of PLK4 results in multiple PLK4 foci around the mother centriole and overproduction of daughter centrioles ${ }^{18,19}$. Overexpression of Cep152 or the cartwheel proteins SAS-6 or STIL also has a similar effect ${ }^{20-23}$. These observations not only indicate that cycling cells execute the one-daughter-centrioleper-mother rule by restricting the levels of several critical proteins but also suggest that MCCs may break this rule by simply upregulating the protein levels. Indeed, when mouse tracheal epithelial cells (MTECs) are induced to form multicilia, they express high levels of these proteins ${ }^{19,24,25}$. The importance of PLK4 and Cep152 in mother centriole-dependent (MCD) centriole overduplication of MTECs is also verified ${ }^{19}$

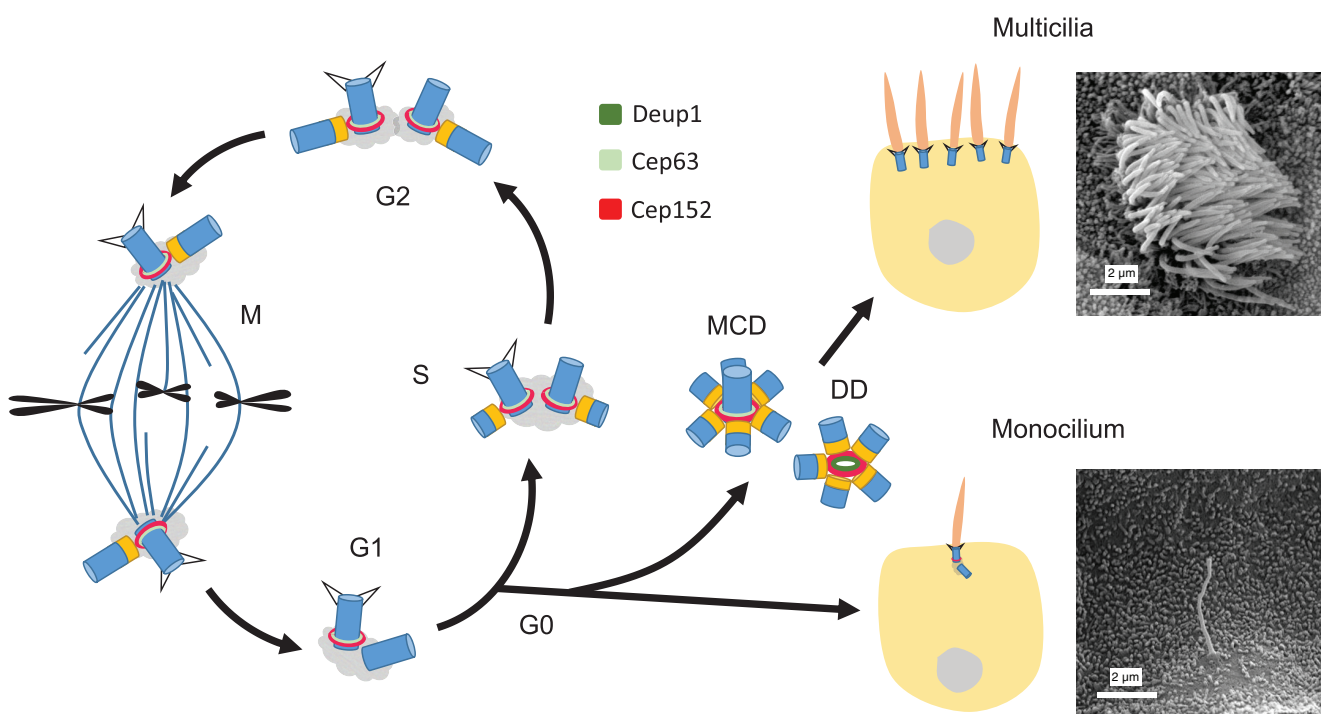

Figure 1. Centriole biogenesis and cilia formation. The centrosome in a G1 cell contains a pair of mother-daughter centrioles. Upon entering the S phase, each centriole starts to duplicate one daughter centriole so that the centriole number remains constant after mitosis (a). When the cell enters G0, the mother centriole can be transformed into the basal body to support monocilium formation (b). Alternatively, both the mother centriole-dependent (MCD) and deuterosome-dependent (DD) pathways can be activated to generate an abundance of centrioles for dense multicilia formation (c). The scanning electron microscopy images show a primary cilium in the collecting duct of mouse kidney and multicilia of a multiciliated cell in mouse tracheal epithelium, respectively. Centrioles are drawn in blue and their cartwheels in orange. 


\section{Deuterosome-dependent centriole assembly}

The discovery of an essential deuterosome component, Deup1 (also called Ccdc67), has promoted the understanding of deuterosomedependent (DD) centriole biogenesis. Strikingly, Deup1 is a paralog of Cep63 ${ }^{19}$. Cep152 binds to both Cep63 and Deup1 to stabilize them and be recruited, respectively, to the mother centriole and the deuterosome ${ }^{19,26}$. Therefore, if we consider the Cep63-Cep152-containing proximal ring of the mother centriole as a platform, or 'cradle', that supports nascent centriole assembly, deuterosomes are analogous cradles, independent of mother centrioles (Figure 2A). In MTECs, deuterosomes appear initially as foci with zero to two associated procentrioles (Figure 2A-B, stage II). Their sizes then enlarge, accompanied by an increase in procentriole numbers (Figure 2A-B, stage III). They are disassembled upon completion of centriole assembly (Figure 2A) ${ }^{19,27}$. Usually 50-100 deuterosomes can be found in a MTEC, sufficient for the production of hundreds of centrioles (Figure 2B) ${ }^{19}$. Mouse ependymal cells (MEPCs) displayed a similar centriole amplification process, but their deuterosomes are usually much larger in size and smaller in number (Figure 2C).

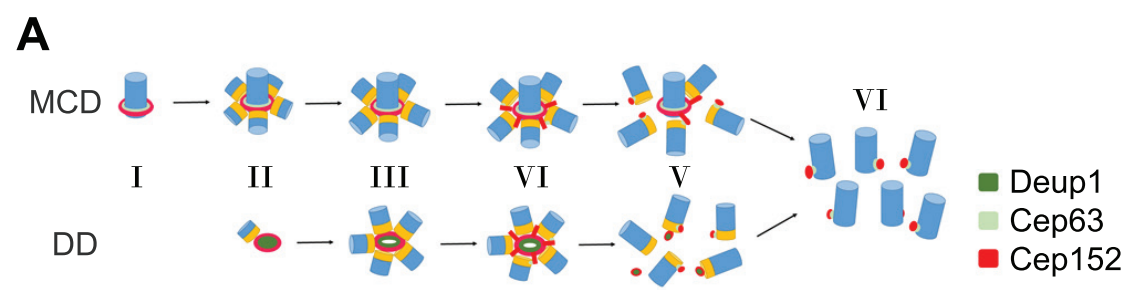

B
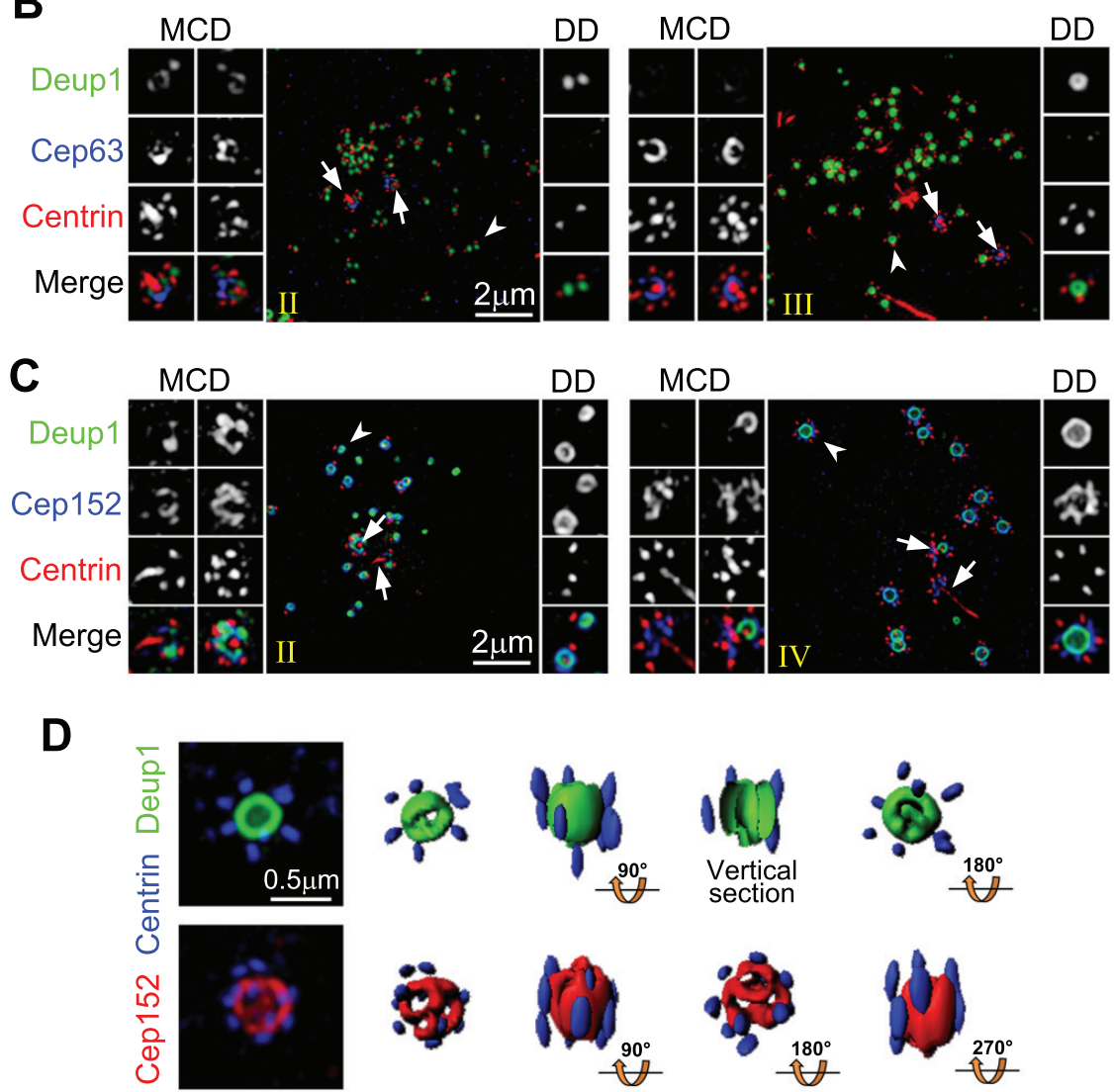

Figure 2. Centriole amplifications in mouse tracheal epithelial cells (MTECs) and mouse ependymal cells (MEPCs). (A) Illustration for centriole amplification stages in MTECs ${ }^{19}$. Centrioles are drawn in blue and their cartwheels in orange. (B) Three-dimensional structured illumination microscopy (3D-SIM) images for MTECs at early stages (II and III) of centriole amplification. MTECs cultured as described previously ${ }^{19}$ were immunostained for Deup1, Cep63, and Centrin and imaged using a DeltaVision OMX V3 microscopic system (GE Healthcare). The mother centrioles (arrows) and representative deuterosomes (arrowheads) are magnified $2 \times$ to show details. (C) 3D-SIM images showing centriole amplification in MEPCs. MEPCs were isolated from neonatal C57BL/6J mice and cultured as described ${ }^{32}$. The cells were fixed at day three after serum starvation and immunostained for Deup1, Cep152, and Centrin. The stages (II and IV) are defined as in the MTECs. Note that MEPC deuterosomes (C) are usually much larger than those in MTECs (B). (D) SIM images of two large MEPC deuterosomes immunostained for Deup1 and Centrin (top row) or Cep152 and Centrin (bottom row). Their 3D profiles are also shown. Abbreviations: DD, deuterosome dependent; MCD, mother centriole dependent. 
The beauty of such a DD pathway is obvious: cycling cells only need to turn off the DD pathway by shutting down Deupl expression to avoid the production of extra centrioles. On the other hand, as MCCs are terminally differentiated and no longer able to enter the cell cycle, turning on the DD pathway and upregulating other genes critical for basal body assembly can safely fulfill their demand on large numbers of basal bodies. For instance, the Multicilin-E2F4/5 complex is known to activate the transcription of Deupl, Plk4, Cep152, and many other centriolar protein genes in $\mathrm{MCCs}^{28-30}$. Other proteins such as cyclin $\mathrm{O}$ appear to fine-tune the transcription program ${ }^{31}$.

\section{Deuterosome structures and components}

Deuterosome size varies remarkably in different tissues and species: for instance, from 100-200 nm (diameter) in rat or mouse MTECs $^{8,19}$ to more than $500 \mathrm{~nm}$ in the mouse oviduct ${ }^{10}$. Larger deuterosomes are capable of supporting more procentrioles. As deuterosomes look mostly ring shaped in transmission EM, they were proposed to be roughly sphere shaped, capable of assembling centrioles in all directions ${ }^{8,10}$. Serial ultra-thin sections of MEPCs support this notion ${ }^{32}$.

Three-dimensional profiling of subdiffraction images from both MTECs and MEPCs, however, suggests that Deup1 and Cep152 are arranged in a ring-shaped configuration in the deuterosome, with the Cep152 signals enwrapping those of Deup1 from outside (Figure 2C) ${ }^{19}$. Such a configuration is topologically analogous to the mother centriole cradle. Only the ends of the deuterosome appear relatively amorphous. For instance, in large deuterosomes such as those of MEPCs, the Cep152 signals may exhibit several 'holes' at each end (Figure 2D). Procentrioles tend to be assembled on the outer wall of the deuterosome but can be found at both ends as well (Figure 2D) ${ }^{19}$.

Whether there are additional proteins to construct the outer wall, fill the center, or cap the ends of the deuterosome is presently unknown. Ccdc78, a coiled coil domain-containing protein, is reported as a deuterosome-specific protein required for centriole amplification in the Xenopus embryonic epidermis ${ }^{33}$. Nonetheless, mouse Ccdc78, expressed either endogenously or exogenously, was not detected on Deup1-positive deuterosomes in our hands, raising the possibility that Ccdc78 may be either an amphibian-specific deuterosome component or even not a bona fide one.

\section{Deuterosome assembly}

How deuterosome components are packed together to form the supramolecular structure is also an important issue. Fibrous granules (also called fibrogranular material or proliferative elements), clouds of material abundant in 40 to $80 \mathrm{~nm}$ granules that coincide with deuterosome formation in MCCs, were proposed to be precursors of the deuterosome ${ }^{8-10}$. PCM-1, a component of fibrous granules, however, failed to show deuterosome localization ${ }^{34}$. Its depletion by RNA interference also didn't impair centriole amplification ${ }^{25}$. Likewise, neither Deup1 nor Cep152 exhibited obvious fibrous granule-like distributions (Figure 2B-C) ${ }^{19}$. Since small deuterosomes tend to emerge in bulk and then grow in synchrony and ectopic expression of Deup1 in cycling cells is sufficient to induce the formation of functional deuterosomes (Figure 2B) ${ }^{19}$, we propose that deuterosomes can be assembled spontaneously (Figure 2A).
Interestingly, a recent publication argues for a totally different mechanism ${ }^{32}$. Based mainly on studies in MEPCs, a model is proposed in which an unknown mechanism recruits Deup1, Ccdc78, and other cradle proteins to a site in the cradle of the young mother centriole to initiate the assembly of both the deuterosome and the daughter centrioles. The deuterosome-procentriole halo is then released so that the site can begin the next assembly cycle. After the release of the last halo, procentrioles on all the deuterosomes start to elongate and mature. Thus, both the deuterosome formation and the massive centriole biogenesis are MCD processes. Deuterosomes function merely as shuttles to carry the daughter centrioles away from their mother centriole into the cytoplasm ${ }^{32,35}$.

This model, despite its uniqueness, still needs further verification. Firstly, it remains to be shown whether this is the sole and universal way of deuterosome generation. Deup1 is capable of mother centriole localization (Figure 2B-C) ) $^{19}$. It is thus understandable that some of the protein there may serve as seeds to initiate deuterosome assembly. Since live imaging in the MEPCs suggests that the generation of one halo requires about two hours ${ }^{32}$, such an efficiency would demand several days to generate the 50-100 deuterosomes in MTECs, while the entire centriole amplification process takes roughly only one day ${ }^{19,32}$. Thus, both the spontaneous and MCD pathways may contribute. Furthermore, there might be multiple deuterosome nucleation sites on both the young and the old mother centrioles (Figure 2B-C). Secondly, the model is apparently incompatible with the observation that the numbers of deuterosome-associated procentrioles increase over time (Figure 2B-C) ${ }^{19}$. Even if one or two daughter centrioles could be carried away from the mother centriole by each nascent deuterosome, their subsequent increase in numbers still argues for the existence of de novo DD centriole biogenesis. Finally, what defines the deuterosome nucleation site on the mother centriole and how the cytoplasmic halos can wait until the last one is released are also issues for future clarification.

\section{Conservation of the deuterosome-dependent pathway} Phylogenetic analysis suggests that Deupl is originated from a common fish ancestor of the lobe-finned fish and tetrapods in the vertebrate evolution to boost cilia density in $\operatorname{MCCs}^{19,36}$. Accordingly, in contrast to the lobe-finned fish (such as lungfish), MCCs of the ray-finned fish (such as zebrafish), which have no Deupl, contain only sparse cilia ${ }^{37,38}$. Many invertebrates, however, possess MCCs with dense multicilia ${ }^{39-42}$. Deuterosome-like ultrastructures have also been reported in some invertebrate species ${ }^{43,44}$. A comprehensive knowledge of strategies for centriole amplification throughout metazoan evolution will thus require an understanding of the mechanisms for multiciliogenesis in the invertebrate.

\section{Conclusions and perspectives}

The mechanism of centriole amplification is both exciting and challenging. Because the sizes of centrioles and deuterosomes are below or close to the optical diffraction limit, technical limitations of imaging are a current major bottleneck restraining studies of centriole amplification in MCCs. Although 3D structured illumination microscopy $(\mathrm{SIM})^{45}$ has proven its power in the past $^{19,32}$, the development and introduction of super-resolution techniques with higher spatial (especially the z-axis) and temporal resolutions ${ }^{46-49}$ are expected to greatly facilitate studies in the field. Furthermore, other cutting-edge techniques such as cryo-electron 
tomography, omics analysis, and computational biology may help to solve issues on the structure, formation, growth, disassembly, and function of the deuterosome as well as the entire mechanism that controls appropriate on-and-off switching of the centriole amplification program.

\section{Abbreviations}

DD, deuterosome dependent; EM, electron microscopy; MCC, multiciliated cell; MCD, mother centriole dependent; MEPC, mouse ependymal cell; MTEC, mouse tracheal epithelial cell; SIM, structured illumination microscopy.

Competing interests

The authors declare that they have no competing interests.

\section{Grant information}

The authors are supported by grants from the National Science Foundation of China (31330045) and the Ministry of Science and Technology of China (2012CB945003).

The funders had no role in study design, data collection and analysis, decision to publish, or preparation of the manuscript.

\section{Acknowledgements}

The authors thank Dr Nathalie Spassky (CNRS, France) for the mouse ependymal cell culture protocol, Drs Steven Brody and Giuliano Callaini for very helpful criticisms and suggestions on the manuscript, Yawen Chen and Shichao Duan for providing the micrographs of multicilia and primary cilium, and Qijun Tang for the illustrations.
1. Nigg EA, Stearns T: The centrosome cycle: Centriole biogenesis, duplication and inherent asymmetries. Nat Cell Biol. 2011; 13(10): 1154-60. PubMed Abstract | Publisher Full Text | Free Full Text

2. Bornens M: The centrosome in cells and organisms. Science. 2012; 335(6067): $422-6$.

PubMed Abstract | Publisher Full Text

3. Ishikawa $\mathrm{H}$, Marshall WF: Ciliogenesis: building the cell's antenna. Nat Rev Mol Cell Biol. 2011; 12(4): 222-34. PubMed Abstract | Publisher Full Text

4. Avidor-Reiss T, Gopalakrishnan J: Building a centriole. Curr Opin Cell Biol. 2013; 25(1): $72-7$.

PubMed Abstract | Publisher Full Text | Free Full Text

5. Gönczy P: Towards a molecular architecture of centriole assembly. Nat Rev Mol Cell Biol. 2012; 13(7): 425-35.

PubMed Abstract | Publisher Full Text

6. Goetz SC, Anderson KV: The primary cilium: a signalling centre during vertebrate development. Nat Rev Genet. 2010; 11(5): 331-44. PubMed Abstract | Publisher Full Text | Free Full Text

7. Brooks ER, Wallingford JB: Multiciliated cells. Curr Biol. 2014; 24(19): R973-82. PubMed Abstract | Publisher Full Text | Free Full Text

8. Sorokin SP: Reconstructions of centriole formation and ciliogenesis in mammalian lungs. J Cell Sci. 1968; 3(2): 207-30. PubMed Abstract

9. Anderson RG, Brenner RM: The formation of basal bodies (centrioles) in the Rhesus monkey oviduct. J Cell Biol. 1971; 50(1): 10-34. PubMed Abstract | Publisher Full Text | Free Full Text

10. Dirksen ER: Centriole morphogenesis in developing ciliated epithelium of the mouse oviduct. J Cell Biol. 1971; 51(1): 286-302. PubMed Abstract | Publisher Full Text | Free Full Text

11. Kalnins VI, Porter KR: Centriole replication during ciliogenesis in the chick tracheal epithelium. Z Zellforsch Mikrosk Anat. 1969; 100(1): 1-30. PubMed Abstract | Publisher Full Text

12. Steinman RM: An electron microscopic study of ciliogenesis in developing epidermis and trachea in the embryo of Xenopus laevis. Am J Anat. 1968; 122(1): 19-55.

PubMed Abstract | Publisher Full Text

13. Cizmecioglu O, Arnold M, Bahtz R, et al.: Cep152 acts as a scaffold for recruitment of PIk4 and CPAP to the centrosome. J Cell Biol. 2010; 191(4): 731-9. PubMed Abstract | Publisher Full Text | Free Full Text

14. Hatch EM, Kulukian A, Holland AJ, et al.: Cep152 interacts with PIk4 and is required for centriole duplication. J Cell Biol. 2010; 191(4): 721-9. PubMed Abstract | Publisher Full Text | Free Full Text

15. Sonnen $\mathrm{KF}$, Schermelleh $\mathrm{L}$, Leonhardt $\mathrm{H}$, et al:: 3D-structured illumination microscopy provides novel insight into architecture of human centrosomes. Biol Open. 2012; 1(10): 965-76.

PubMed Abstract | Publisher Full Text | Free Full Text

16. Bettencourt-Dias M, Rodrigues-Martins A, Carpenter L, et al: SAK/PLK4 is required for centriole duplication and flagella development. Curr Biol. 2005; 15(24): 2199-207. PubMed Abstract | Publisher Full Text

17. Habedanck R, Stierhof YD, Wilkinson $\mathrm{CJ}$, et al: The Polo kinase Plk4 functions in centriole duplication. Nat Cell Biol. 2005; 7(11): 1140-6.

PubMed Abstract | Publisher Full Text

18. Kleylein-Sohn J, Westendorf J, Le Clech M, et al.: Plk4-induced centriole biogenesis in human cells. Dev Cell. 2007; 13(2): 190-202. PubMed Abstract | Publisher Full Text

19. $\mathrm{F}$ Zhao H, Zhu L, Zhu Y, et al:: The Cep63 paralogue Deup1 enables massive de novo centriole biogenesis for vertebrate multiciliogenesis. Nat Cell Biol. 2013; 15(12): 1434-44.

PubMed Abstract | Publisher Full Text | F1000 Recommendation

20. Dzhindzhev NS, Yu QD, Weiskopf K, et al:: Asterless is a scaffold for the onset of centriole assembly. Nature. 2010; 467(7316): 714-8. PubMed Abstract | Publisher Full Text

21. Strnad P, Leidel S, Vinogradova T, et al:: Regulated HsSAS-6 levels ensure formation of a single procentriole per centriole during the centrosome duplication cycle. Dev Cell. 2007; 13(2): 203-13. PubMed Abstract | Publisher Full Text | Free Full Text

22. Vulprecht $\mathrm{J}$, David A, Tibelius A, et al:: STIL is required for centriole duplication in human cells. J Cell Sci. 2012; 125(Pt 5): 1353-62. PubMed Abstract | Publisher Full Text

23. Arquint C, Sonnen KF, Stierhof YD, et al:: Cell-cycle-regulated expression of STIL controls centriole number in human cells. J Cell Sci. 2012; 125(Pt 5): 1342-52. PubMed Abstract | Publisher Full Text

24. Hoh RA, Stowe TR, Turk E, et al:: Transcriptional program of ciliated epithelial cells reveals new cilium and centrosome components and links to human disease. PLoS One. 2012; 7(12): e52166.

PubMed Abstract | Publisher Full Text | Free Full Text

25. Vladar EK, Stearns T: Molecular characterization of centriole assembly in ciliated epithelial cells. J Cell Biol. 2007; 178(1): 31-42. PublMed Abstract | Publisher Full Text | Free Full Text

26. Sir JH, Barr AR, Nicholas AK, et al: A primary microcephaly protein complex forms a ring around parental centrioles. Nat Genet. 2011; 43(11): 1147-53. PubMed Abstract | Publisher Full Text | Free Full Text

27. Tang TK: Centriole biogenesis in multiciliated cells. Nat Cell Biol. 2013; 15(12) $1400-2$.

PubMed Abstract | Publisher Full Text

28. F Ma L, Quigley I, Omran $\mathrm{H}$, et al.: Multicilin drives centriole biogenesis via E2f proteins. Genes Dev. 2014; 28(13): 1461-71. PubMed Abstract | Publisher Full Text | Free Full Text | F1000 Recommendation

29. Balestra FR, Gönczy P: Multiciliogenesis: multicilin directs transcriptional activation of centriole formation. Curr Biol. 2014; 24(16): R746-9. PubMed Abstract | Publisher Full Text

30. F Stubbs JL, Vladar EK, Axelrod JD, et al:: Multicilin promotes centriole 
assembly and ciliogenesis during multiciliate cell differentiation. Nat Cell Biol. 2012; 14(2): 140-7.

PubMed Abstract | Publisher Full Text | Free Full Text | F1000 Recommendation

31. F Funk MC, Bera AN, Menchen T, et al: Cyclin O (Ccno) functions during deuterosome-mediated centriole amplification of multiciliated cells. EMBO J. 2015; 34(8): 1078-89.

PubMed Abstract | Publisher Full Text | Free Full Text | F1000 Recommendation

32. F Al Jord A, Lemaître Al, Delgehyr N, et al:: Centriole amplification by mother and daughter centrioles differs in multiciliated cells. Nature. 2014; 516(7529): $104-7$.

PubMed Abstract | Publisher Full Text | F1000 Recommendation

33. Klos Dehring DA, Vladar EK, Werner ME, et al:: Deuterosome-mediated centriole biogenesis. Dev Cell. 2013; 27(1): 103-12. PubMed Abstract | Publisher Full Text | Free Full Text

34. Kubo A, Sasaki H, Yuba-Kubo A, et al.: Centriolar satellites: molecular characterization, ATP-dependent movement toward centrioles and possible involvement in ciliogenesis. J Cell Biol. 1999; 147(5): 969-80. PubMed Abstract | Publisher Full Text | Free Full Text

35. Meunier A, Spassky N: Centriole continuity: out with the new, in with the old. Curr Opin Cell Biol. 2016; 38: 60-7.

PubMed Abstract | Publisher Full Text

36. F Amemiya CT, Alföldi J, Lee AP, et al:: The African coelacanth genome provides insights into tetrapod evolution. Nature. 2013; 496(7445): 311-6. PubMed Abstract | Publisher Full Text | Free Full Text | F1000 Recommendation

37. Kramer-Zucker AG, Olale F, Haycraft CJ, et al:: Cilia-driven fluid flow in the zebrafish pronephros, brain and Kupffer's vesicle is required for normal organogenesis. Development. 2005; 132(8): 1907-21. PubMed Abstract | Publisher Full Text

38. Kemp A: Role of epidermal cilia in development of the Australian lungfish, Neoceratodus forsteri (Osteichthyes: Dipnoi). J Morphol. 1996; 228(2): 203-21. Publisher Full Text

39. Basti L, Endo M, Segawa S, et al.: Prevalence and intensity of pathologies induced by the toxic dinoflagellate, Heterocapsa circularisquama, in the Mediterranean mussel, Mytilus galloprovincialis. Aquat Toxicol. 2015; 163: 37-50. PubMed Abstract | Publisher Full Text
40. F Azimzadeh J, Wong ML, Downhour DM, et al: Centrosome loss in the evolution of planarians. Science. 2012; 335(6067): 461-3.

PubMed Abstract | Publisher Full Text | Free Full Text | F1000 Recommendation

41. Good MJ, Stommel EW, Stephens RE: Mechanical sensitivity and cell coupling in the ciliated epithelial cells of Mytilus edulis gill. An ultrastructural and developmental analysis. Cell Tissue Res. 1990; 259(1): 51-60.

PubMed Abstract | Publisher Full Text

42. Aono K, Fusada A, Fusada Y, et al.: Upside-down gliding of Lymnaea. Biol Bull. 2008; 215(3): 272-9.

PubMed Abstract | Publisher Full Text

43. Ferraguti M, Fascio $U$, Boi S: Mass production of basal bodies in paraspermiogenesis of Tubificinae (Annelida, Oligochaeta). Biol Cell. 2002; 94(2): 109-15 PubMed Abstract | Publisher Full Text

44. Ash BM, Stephens RE: Ciliogenesis during the sequential formation of molluscan gill filaments. Dev Biol. 1975; 43(2): 340-7.

PubMed Abstract | Publisher Full Text

45. F Schermelleh L, Carlton PM, Haase S, et al.: Subdiffraction multicolor imaging of the nuclear periphery with 3D structured illumination microscopy. Science. 2008; 320(5881): 1332-6.

PubMed Abstract | Publisher Full Text | Free Full Text | F1000 Recommendation

46. Schermelleh L, Heintzmann R, Leonhardt $\mathrm{H}$ : A guide to super-resolution fluorescence microscopy. J Cell Biol. 2010; 190(2): 165-75. PubMed Abstract | Publisher Full Text | Free Full Text

47. Vicidomini G, Moneron G, Han KY, et al:: Sharper low-power STED nanoscopy by time gating. Nat Methods. 2011; 8(7): 571-3.

PubMed Abstract | Publisher Full Text

48. F Li D, Shao L, Chen BC, et al.: ADVANCED IMAGING. Extended-resolution structured illumination imaging of endocytic and cytoskeletal dynamics. Science. 2015; 349(6251): aab3500.

PubMed Abstract | Publisher Full Text | Free Full Text | F1000 Recommendation

49. $\mathrm{F}$ Xu K, Zhong G, Zhuang X: Actin, spectrin, and associated proteins form a periodic cytoskeletal structure in axons. Science. 2013; 339(6118): 452-6. PubMed Abstract | Publisher Full Text | Free Full Text | F1000 Recommendation 


\section{Open Peer Review}

\section{Current Peer Review Status:}

\section{Editorial Note on the Review Process}

Faculty Reviews are review articles written by the prestigious Members of Faculty Opinions. The articles are commissioned and peer reviewed before publication to ensure that the final, published version is comprehensive and accessible. The reviewers who approved the final version are listed with their names and affiliations.

\section{The reviewers who approved this article are:}

\section{Version 1}

\section{Giuliano Callaini}

Department of Life Sciences, University of Siena, Siena, Italy Competing Interests: No competing interests were disclosed.

\section{Steven Brody}

Department of Medicine, Washington University School of Medicine, St. Louis, MO, USA

Competing Interests: No competing interests were disclosed.

The benefits of publishing with F1000Research:

- Your article is published within days, with no editorial bias

- You can publish traditional articles, null/negative results, case reports, data notes and more

- The peer review process is transparent and collaborative

- Your article is indexed in PubMed after passing peer review

- Dedicated customer support at every stage

For pre-submission enquiries, contact research@f1000.com 